\title{
PERILAKU HIDUP BERSIH DAN SEHAT PADA TATANAN RUMAH TANGGA DAN KEJADIAN PENYAKIT DIARE
}

\author{
Fajar Rahmadani S, Sri Mardojo, Imam Thohari
}

\begin{abstract}
Diarrhea remains a major health problem in Surabaya. Based on data from Surabaya City Health Service in 2012 there were 92,072 cases of diarrhea, and the village of Wonokusumo contributed 255 cases in 2012 and more than doubled, as many as 608 cases in 2013.

This study aims to describe the practice of PHBS in the household setting and the incidence of diarrhea. This is a non-experimental study using descriptive data analyses. The instrument used in gathering data was a questionnaire and observation sheet.

Results of of the study with regard to knowledge, attitudes, and practice and implementation of PHBS principles by housewives. In the case-group, with regard to knowledge aspect, the accomplishment were gond or $38.4 \%$, moderate or $44.2 \%$, and poor or $17.4 \%$, while the non case-group has different accomplishment, good or $15.1 \%$, moderate or $61.6 \%$. and poor or $23.3 \%$.

Results with regard to attitude among the respondents in the case group was good $19.2 \%$, moderate $46.2 \%$, and poor $17.3 \%$, while in the non case-group the results were good $39.5 \%$, moderate $54.7 \%$, and poor $5.8 \%$. Results for practices in case group were good $18.6 \%$, moderate $73.3 \%$, and poor $8.1 \%$, while in non case group the results were good $7 \%$, moderate $77.9 \%$, and poor $15.1 \%$. Finally, with regard to the application of PHBS princuples, the case-group were mostly unhealthy $(74.4 \%)$, whereas in the non-case group the most common response was healthy $(65.1 \%)$.

Analyses of the above data indicated that in terms of knowledge, attitude, and practice, most housewives responded a moderate value. Interms of PHBS implementation the case-group showed unhealthy response than the non-case group.

By observing the 10 indicators of good household PHBS the family will be protected from diseases especially diarrhea
\end{abstract}

Keywords: PHBS, household, case, non-case

\section{PENDAHULUAN}

Penyakit diare sampai saat ini masih menjadi masalah kesehatan dunia. Data Organisasi Kesehatan Dunia (WHO) tahun 2008 menunjukkan bahwa $15 \%$ dari kematian anak dibawah 5 tahun disebabkan oleh penyakit diare (WHO, 2008 dalam Supiyan, Reni Zulfitri, \& Rismawado Wofers, 2012).

Penyakit diare merupakan salah satu penyakit berbasis lingkungan yang disebabkan oleh faktor lingkungan serta perilaku hidup bersih dan sehat (PHBS) yang masih rendah.

Kasus penyakit diare di Kota Surabaya masih terbilang cukup tinggi. Berdasarkan data dari Dinas Kesehatan Kota Surabaya pada tahun 2012 terdapat 92.072 kasus penyakit diare. Puskesmas Wonokusumo Kecamatan Semampir menyumbang 255 kasus di tahun 2012, kemudian pada tahun 2013 meningkat dua kali lipat sebanyak 608 kasus. Hasil rekapitulasi survey PHBS yang dilakukan dari $110 \mathrm{KK}$, dinyatakan $85 \mathrm{KK}$ tidak sehat dan $25 \mathrm{KK}$ dinyatakan sehat.

Kalangan ilmuwan berpendapat bahwa determinan utama dari derajat kesehatan masyarakat, selain kondisi lingkungan adalah perilaku. Sehingga upaya mengubah perilaku masyarakat perlu dilakukan melalui program pembinaan PHBS.

\section{TUJUAN PENELITIAN}

Mengetahui PHBS pada tatanan rumah tangga di wilayah kerja Puskesmas Wonokusumo, Kecamatan Semampir Kota Surabaya tahun 2014.

\section{METODE PENELITIAN}

Penelitian ini termasuk jenis penelitian non experimen dan analisis datanya bersifat deskriptif. Penelitian ini dilakukan di wilayah Kerja Puskesmas Wonokusumo Kecamatan Semampir Kota Surabaya. Waktu penelitian Desember 2013Juni 2014.

Populasi dari penelitian ini adalah penderita penyakit diare yang terjadi selama tahun 2013 di Puskesmas Wonokusumo Kelurahan Wonokusumo dengan jumlah kasus 608 kasus. Besar sampel adalah 86 sampel untuk kelompok kasus dan 86 sampel kelompok bukan kasus (kontrol). 


\section{HASIL PENELITIAN}

Secara umum Perilaku Hidup yang baik akan menghasilkan tingkat kesehatan yang baik pula.

WonoKusumo. Diantara kelompok yang PHBS nya

Kiranya hal ini sudah terbukti di Puskesmas

sehat jumlah kasus Diare juga lebih kecil.

Tabel 1: PHBS Tatanan Rumah Tangga Di Puskesmas Wonokusumo

\begin{tabular}{|c|c|c|c|c|}
\hline \multirow[b]{2}{*}{ No } & \multirow[b]{2}{*}{ Status PHBS } & \multicolumn{3}{|c|}{ Kejadian Penyakit Diare } \\
\hline & & Tidak Ada Kasus (\%) & $\begin{array}{c}\text { Kasus } \\
(\%)\end{array}$ & $\mathbf{N}$ \\
\hline 1 & Sehat & $\begin{array}{c}56 \\
(65,1 \%) \\
\end{array}$ & $\begin{array}{c}22 \\
(25,6 \%)\end{array}$ & 78 \\
\hline 2 & Tidak Sehat & $\begin{array}{c}30 \\
(43,9 \%) \\
\end{array}$ & $\begin{array}{c}64 \\
(74,4 \%)\end{array}$ & 94 \\
\hline & Jumlah & $\begin{array}{c}86 \\
(100 \%)\end{array}$ & $\begin{array}{c}86 \\
(100 \%)\end{array}$ & 172 \\
\hline
\end{tabular}

Dari hasil observasi dan penilaian PHBS tatanan rumah tangga diketahui bahwa kelompok kasus mempunyai perilaku hidup bersih dan sehat yang masih kurang, hal ini di ketahui bahwa dari 86 rumah tangga pada kelompok kasus $74,4 \%$ masih dinyatakan "Tidak Sehat". Sedangkan untuk kelompok yang tidak terdapat kasus, sebagian besar perilaku hidup bersih dan sehat sudah baik, yaitu dari 86 rumah tangga pada kelompok tidak ada kasus $65,1 \%$ sudah dikatakan "Sehat".

Tabel 2: Pengetahuan Ibu Rumah Tangga Tentang PHBS dan Kejadian Kasus Diare

\begin{tabular}{|c|c|c|c|c|}
\hline \multirow{2}{*}{ No } & \multirow{2}{*}{$\begin{array}{c}\text { Pengetahuan } \\
\text { Ibu Rumah Tangga }\end{array}$} & $\begin{array}{c}|c| \\
\text { Tidak Ada Kasus } \\
(\%)\end{array}$ & $\begin{array}{c}\text { Kasus } \\
(\%)\end{array}$ & N \\
\hline 1 & Baik & $\begin{array}{c}33 \\
(38,4 \%)\end{array}$ & $\begin{array}{c}13 \\
(15,1 \%)\end{array}$ & 46 \\
\hline 2 & Cukup & $\begin{array}{c}38 \\
(44,2 \%)\end{array}$ & $\begin{array}{c}53 \\
(61,6 \%)\end{array}$ & 91 \\
\hline 3 & Kurang & $\begin{array}{c}15 \\
(17,4 \%)\end{array}$ & $\begin{array}{c}20 \\
(23,3 \%)\end{array}$ & 35 \\
\hline & Jumlah & $\begin{array}{c}86 \\
(100 \%)\end{array}$ & $\begin{array}{c}86 \\
(100 \%)\end{array}$ & 172 \\
\hline
\end{tabular}

Berdasarkan tabel 2 diatas dapat diketahui bahwa pengetahuan untuk kelompok kasus diare yang memiliki pengetahuan kurang lebih banyak dari pada kelompok tidak ada kasus, yaitu dengan jumlah $20(23,3 \%)$.

Tabel 3: Sikap Ibu Rumah Tangga Tentang PHBS dengan Kejadian Kasus Diare di Wonokusumo

\begin{tabular}{|c|c|c|c|c|}
\hline \multirow{2}{*}{ No } & \multirow{2}{*}{$\begin{array}{c}\text { Sikap } \\
\text { Ibu Rumah Tangga }\end{array}$} & \multicolumn{3}{|c|}{ Kejadian Penyakit Diare } \\
\cline { 2 - 5 } & Bidak Ada Kasus (\%) & $\begin{array}{c}\text { Kasus } \\
(\%)\end{array}$ & N \\
\hline 1 & Cukup & $\begin{array}{c}34 \\
(39,5 \%)\end{array}$ & $\begin{array}{c}20 \\
(19,2 \%)\end{array}$ & 54 \\
\hline 2 & \multirow{4}{*}{$\begin{array}{c}47 \\
(54,7 \%)\end{array}$} & $\begin{array}{c}48,2 \%) \\
(46,2 \%)\end{array}$ & 95 \\
\hline \multirow{2}{*}{ No } & Sikap & \multicolumn{3}{|c|}{ Kejadian Penyakit Diare } \\
\hline & Ibu Rumah Tangga & Tidak Ada Kasus(\%) & $\begin{array}{c}\text { Kasus } \\
(\%)\end{array}$ & N \\
\hline 3 & Kurang & $\begin{array}{c}5 \\
(5,8 \%)\end{array}$ & $\begin{array}{c}18 \\
(17,3 \%)\end{array}$ & 23 \\
\hline & Jumlah & $\begin{array}{c}86 \\
(100 \%)\end{array}$ & $\begin{array}{c}86 \\
(100 \%)\end{array}$ & 172 \\
\hline
\end{tabular}


Berdasarkan tabel tabel 3 diatas dapat diketahui bahwa kelompok kasus yang memiliki sikap kurang yang lebih banyak dari pada kelompok tidak ada kasus dengan jumlah $18(17,3 \%)$. Dan ditinjau dari hasil PHBS kelompok kasus sebagian besar "Tidak Sehat".

Tabel 4: Tindakan Ibu Rumah Tangga Tentang PHBS dan Kejadian Kasus Diare Di Wonokusumo

\begin{tabular}{|c|c|c|c|c|}
\hline \multirow{2}{*}{ No } & \multirow{2}{*}{$\begin{array}{c}\text { Tindakan } \\
\text { Ibu Rumah Tangga }\end{array}$} & \multicolumn{3}{|c|}{ Kejadian Penyakit Diare } \\
\cline { 3 - 5 } & Baik & $\begin{array}{c}\text { Tidak Ada } \\
\text { Kasus (\%) }\end{array}$ & $\begin{array}{c}\text { Kasus } \\
(\%)\end{array}$ & N \\
\hline 1 & Cukup & $\begin{array}{c}16 \\
(18,6 \%)\end{array}$ & $\begin{array}{c}6 \\
(7 \%)\end{array}$ & 22 \\
\hline 2 & Kurang & $\begin{array}{c}63 \\
(73,3 \%)\end{array}$ & $\begin{array}{c}67 \\
(77,9 \%)\end{array}$ & 130 \\
\hline 3 & Jumlah & $\begin{array}{c}7 \\
(8,1 \%)\end{array}$ & $\begin{array}{c}13 \\
(15,1 \%)\end{array}$ & 20 \\
\hline & & $\begin{array}{c}86 \\
(100 \%)\end{array}$ & $\begin{array}{c}86 \\
(100 \%)\end{array}$ & 172 \\
\hline
\end{tabular}

Berdasarkan tabel 4 diatas dapat diketahui bahwa kelompok kasus diare memiliki nilai tindakan kurang lebih banyak dari pada kelompok bukan kasus dengan jumlah 15,1\%.

\section{KESIMPULAN}

Berdasarkan analisis data diatas diketahui bahwa pengetahuan, sikap, dan tindakan ibu rumah tangga sebagian besar mendapat nilai cukup. Dan untuk kelompok kasus diare yang memiliki PHBS

\section{DAFTAR PUSTAKA}

Andrianto,Pettrus, 1995. Penatalaksanaan dan Pencegahan Diare Akut. Jakarta : WHO : $1,29-32$

Chandra, Budiman, 2007. Pengantar Kesehatan Lingkungan. Jakarta : Buku Kedokteran egc :40, 124-125

Depkes RI.1998, Petunjuk Teknis Kesiapsiagaan dan Penanggulangan Bencana Bidang Penyakit Menular \& Kesehatan Lingkungan.Jakarta : 17-18.

Depkes RI. 2008, Strategi Nasional Sanitasi Total Berbasis Masyarakat. Jakarta

Dinkesprov Jatim, 2001. Pedoman Hidup Bersih dan Sehat.Surabaya: 1,4.

Dinkesprov Jatim, 2012.Rumah Tangga BerPerilaku Hidup Bersih dan Sehat. Surabaya: 2-48.

Dinkesprov Jatim,2013.Profil Kesehatan Provinsi Jawa Timur Tahun 2012. Surabaya: 28

Ditjen P2PL,2011. Panduan Sosialisasi Tatalaksana Diare Pada Balita.Jakarta : Kemenkes RI : 14 tidak sehat lebih banyak dari pada kelompok yang tidak ada kasus.

\section{SARAN}

Bagi masyarakat perlu untuk mengikuti kegiatan penyuluhan PHBS agar meningkatkan pengetahuan, sikap dan tindakan yang berkaitan dengan pentingnya kesehatan masyarakat. Bagi instansi terkait perlu peningkatan kegiatan kesehatan masyarakat seperti penyuluhan dan perlombaan keluarga sehat dalam ber PHBS.

Ditjen P2PL,2011.Buku Saku Petugas Kesehatan Lintas Diare Lima Llangkah Tuntaskan Diare.Jakarta : Depkes RI : 5

Kementerian Kesehatan RI, 2011.Situasi Diare di Indonesia

Kepmenkes RI Nomor 852/Menkes/SK/IX/2008 Tentang Srategi Nasional Sanitasi Total Berbasis Masyarakat.

Notoatmodjo, Sukidjo, 2003. Pendidikan dan Perilaku Kesehatan. Jakarta : Rineka Cipta : 12

Notoatmodjo, Sukidjo, 2010. IImu Perilaku Kesehatan. Jakarta : Rineka Cipta : 2033,87

Notoatmodjo, Sukidjo, 2012. Metodologi Penelitian Kesehatan. Jakarta : Rineka Cipta

Permenkes RI Nomor 2269/MENKES/PER/XI/2011 Tentang Pedoman Pembinaan Perilaku Hidup Bersih dan Sehat (PHBS).

Widjaja, 2003. Mengatasi Diare dan Keracunan Pada Balita. Jakarta : Kawan Pustaka : 1-13, 41-55. 